\title{
Quality Assurance in a University of Technology in Context of the Three Elements: Quality, Standards and Relevance
}

\author{
Prof CM van der Bank \\ Human Sciences, \\ Vaal University of Technology \\ Cel: +27828083249/riana@vut.ac.za \\ R L Basson \\ Vaal University of Technology \\ Cel: +2716 9509272/rochelle@mailbox.co.za
}

\section{Doi:10.5901/jesr.2014.v4n1p107}

\begin{abstract}
The concern regarding guaranteed quality in Higher Education in a University of Technology in South Africa creates an opportunity to align the elements of quality assurance - namely quality, standards and relevance - that contribute to the equity and effectiveness of the quality assurance process in higher education. These elements focus on the quality assurance efforts of the institution and the problems faced by students while attempting to adhere to the quality standards in Universities of Technology in South Africa. This paper discusses current quality assurance in the environment of teaching and learning, contextualising the Vaal University of Technology with reference to the Teaching and Learning Model (2012).
\end{abstract}

Keywords: Education, Quality, Standards and Management System

\section{Introduction}

Kruger notes that before 1994 there were 19 different Education departments in South Africa that were separated along the lines of race, geography and beliefs. This created an imbalance in the education of learners. The situation called for transformation in the education system that would address the social, political and economic discrimination and inequalities of a class, race, gender, institutional and spatial nature profoundly shaped, and continue to shape in South African higher education (Kruger, 2010:4). Given this, South Africa's new democratic government committed itself in 1994 to transforming higher education as well as the inherited apartheid social and economic structure and institutionalising a new social order (Badat, 2010:5). The documents that provided the framework for the educational transformation are The White Paper on Education and Training (1995), the South African Qualifications Act No. 58 of 1995 and the National Education Policy Act No. 27 (1996). In White Paper No. 1 (1995), the concept of a National Qualifications Framework (NQF) that would provide a single, coherent and unified approach to education and training was put forward. The NQF was developed and implemented by the South African Qualifications Authority Act No. 58 of 1995. This Act also provides for a coordinating structure referred to as the South African Qualifications Authority (SAQA) (Kruger 2010:17).

The Constitution of South Africa, Act 108 of 1996, contains the Bill of Rights. These are the values and principles that underpin the laws and policies of the country, and all policies that government develops should be a way of making these values real to higher education in South Africa (Horn, Huygen, Woodward and Smith 2009:145).

The South African Qualifications Authority (SAQA) (2000:4) observes that education and training have been contested terrain throughout most of South Africa's history. The roots of the National Qualification Framework (NQF) lie in these contestations and in the necessity for all South Africans to be able to equip themselves with the tools needed to negotiate life positively and productively. Thus, South Africa has a pressing need for more graduates of good quality, to take forward all forms of social and economic development. It also needs more graduates to build up the education system itself by providing a strong new generation of teachers, college lecturers, academics and education leaders (Committee on Higher Education (CHE) 2013:15).

The previous outline of the quality system of the NQF highlights the holistic quality management system that is 
required for SAQA to realise its objective of enhancing the quality of education and training. The outline below focuses on the structures and processes required for the quality assurance system associated with the NQF (South African Qualifications Authority, 2000:9). The role of quality assurance in the national education and training system is defined by Kruger (2010:23) as ensuring that all aspects of the system contribute to excellent learning opportunities as well as valuable qualifications, for example checking of training material and resources, education and training providers, etc. Brown, Race and Smith (1997:2) postulate that quality assurance refers to accountability and reflects external interest and requirements, depends on inspection, involves extrinsic motivation, is subject to external control and focuses on information.

The South African Qualifications Authority (SAQA) (2000:3) posits that the quality assurance process consists of only two elements, standards and quality, which are built on the following basic tenets: knowledge, relevant to the current world and the national system of education and training, which must balance the need of quality education for all. The first element, quality, is defined by Ball (1985), Reynolds (1986) and Brennan et al. (1992) from a more pragmatic and epistemologically more viable approach, as 'fitness for purpose' as quoted by Craft (1994:170). On the other hand, the South African Qualifications Authority (SAQA) (2000:7) postulates that 'quality is not a thing, quality is an ongoing event'. In line with other theorists, Nightingale et al. (1994:7) allocated five approaches to quality: quality equals high standards, quality as consistency or zero defects; quality as fitness for purpose (shared by Ball et al.) quality as value for money and quality as transformative.

The second element, standards, is defined by the South African Qualifications Authority (SAQA) (2000:5) as being expressed in terms of a nationally agreed framework and internationally acceptable outcomes. Barnet (1992a) postulates that standards are a set of criteria against which an enterprise is judged (Nightingale et al. 1994:8). The third element, relevance, is defined by the South African Qualifications Authority (SAQA) (2000:7) as being and remaining responsive to national developments; Dlamini (2009:17) agrees with and provides the same definition.

With reference to an international approach, government demands for quality assurance were attended to in both the United Kingdom and Australia. National governments have expended a great deal of effort on bringing about massive change to the systems of higher education. The principal documents outlining these changes are two UK White Papers (DEC, 1987, 1991), an Australian White Paper (Dawkins, 1988) and several Australian Higher Education Council documents (HEC, 1990, 1992a, 1992C). Oddly enough, much that has happened under a Conservative government in Britain and under a Labour government in Australia has resulted in similar outcomes: the abolition of binary systems, forced amalgamations of smaller institutions, overhaul of the various government bodies advising on and regulating higher education, changed funding bases, reduction of resources, increased numbers of students, improved access for 'non-traditional' students and so on (Nightingale and O'Neil 1994:16).

Based on the foregoing discussion, this paper looks at three elements of quality assurance in higher education. In order to develop the argument logically, quality will be discussed first, and this discussion will be followed by an interrogation of standards. Finally a discussion on relevance will be entered into.

\section{Problem Statement}

Quality in South African higher education has suffered seriously as it struggles with massive expansion for education access, equity and equality in a context of profound political, social and economic changes and severe financial crisis (Badat, 2010:11). The challenges of transformation in higher education and training institutions in South Africa have included the definition of the purposes and goals of higher education; extensive policy research, policy formulation, adoption, and implementation in the areas of governance, funding, academic structure and programmes and quality assurance; the enactment of new laws and regulations; and major restructuring and reconfiguration of the higher education institutional landscape and of institutions. These initiatives have often tested the capacities and capabilities of the state and higher education institutions and have affected the pace; nature and outcomes of change (Badat, 2010: 45). Based on these problems, the research questions are:

- What are the three elements of quality assurance of higher education?

- How is the Teaching and Learning Model (2012) of the Vaal University of Technology related to quality assurance?

- How are equity, efficiency and effectiveness ensured at the Vaal University of Technology?

These problems can be encapsulated by the following questions: 


\section{Aims of the study are to:}

- Describe the three elements of quality assurance of higher education.

- Investigate how the Teaching and Learning Model (2012) of the Vaal University of Technology is related to quality assurance.

- Understand how equity, efficiency and effectiveness ensured at the Vaal University of Technology are ensured.

The South African Qualifications Authority (SAQA) (2000:3) states that the practice in outlining and developing the integrated approach to Outcomes-Based Education and Training in South Africa has been to use the word 'standards' for the units and qualifications registered on the NQF and 'quality assurance' for learning and assessment. According to van der Horst and McDonald (1997), OBE can be described as an approach that requires educators and learners to focus their attention on the desired end result, i.e. the outcomes of learning, and the instructive and learning process that will guide the learners to these end results. In OBE, learning is directed towards the outcomes learners should achieve.

Two key elements 'standards' and 'quality' and the NQF standards setting and quality assurance processes are built on the following basic tenets (South African Qualifications Authority (SAQA) 2000:3):

a) Knowledge relevant to the current world is created through partnerships amongst various groupings in society, from academics and researchers to business, from workers to professional experts, from government to community organisations and from learners to professors. In other words, knowledge creation is no longer the preserve of narrowly defined groups of 'experts'; and

b) The national system of education and training must balance the need for quality education for all citizens with the need for flexibility to cater for the wide-ranging circumstances that face learners and the wide-ranging options for delivering what constitutes relevant credits and qualifications. In other words, it must balance society's needs with the needs of the individual.

Relevance is not included in the basic tenets. In the context of this paper, 'relevance', in the author's opinion, refers to a curriculum which relates to the actual industry. The curriculum should prepare the students in the classroom for the workplace environment. This challenge is bridged by role-play, creative and innovative teaching or facilitation and the designing and use of simulation rooms. Relevance can be assigned to both the basic tenets: the knowledge that the learner obtains should equip the learner, in other words, must be relevant to what the learner needs to know for the workplace; and the national system of education and training should prioritise national education and relate the curriculum and policies to the workplace.

\section{Literature Review}

\subsection{The Teaching and Learning Model (2012) of Vaal University of Technology relates to effectiveness:}

The Vaal University of Technology prioritises orientation as a matter of urgency for students entering a system of higher education. The Teaching and Learning Model (2012:16) of the Vaal University of Technology maintains that orientation is important to (amended): provide support with transition and enculturation; introduce students to student life, to avoid stress and anxiety; illuminate under-preparedness; brief learners on institutional factors; address environmental and ecological topics; address the diversity of the student-mass; prevent educational alienation; encourage actual practices in the classroom; and address issues of identity and self. Learners are not 'blank slates' but come to the engagement with expectations, already having had experiences, and what they gain from the engagement, or what they learn, is, to a significant extent, predetermined by this ongoing dynamic of a process of lifelong learning. In my view and in the context of this assignment, a student who undergoes an effective orientation programme will be more comfortable and productive in the new learning environment, and this will result in effectiveness.

Teaching is effective only if learning takes place (unknown author). The Teaching and Learning Model (2012:19) of Vaal University of Technology proffers six facets of understanding that can assist in preparing students for learning, namely:

1. Definition: The students should be able to answer 'why' questions;

2. Interpretation: Because the goal of constructivist approaches to education understands that it is anchored in contexts that are personally meaningful to the student, connecting learning to the context of application is important;

3. Application: The ability to use knowledge effectively in new situations and diverse contexts; 
4. Perspective: Critically evaluating the course content form a variety of perspectives and in a larger social context;

5. Empathy: The ability to identify with another person's feelings and world view is an important educational goal. The idea is to help students increase both their advocacy and inquiry skills; and

6. Self-knowledge: Wisdom to know one's ignorance and how one's patterns of thought and action inform as well as prejudice understanding.

The Teaching and Learning Model (2012:23) of Vaal University of Technology posits social constructivism as one of the learning theories that inform teaching at the institution. Powell and Kalina (2009:243) describe social constructivism as a highly effective method of teaching from which all students can benefit, since collaboration and social interaction are incorporated. Powell and Kalina (2009:243) further state that Lev Vygotsky, the founding father of social constructivism believed social interaction was an integral part of learning.

As noted by Powell and Kalina (2009:243), all the research and theories of Vygotsky (1962) are collectively involved in social constructivism and language development such as cognitive dialogue, the zone of proximal development, social interaction, culture and inner speech. Understanding his theories on building a classroom where interaction is prominent helps develop effective classrooms. Vygotsky's theory of development and all of its language aspects are various concepts that are part of social constructivism. Social constructivism argues that meaning and knowledge are created through social interactions, and new skills, knowledge and understanding derive, in significant part, from what people already know and believe.

Social constructivism is an efficient learning facilitation method which involves interaction between the lecturer and students. Large amounts of knowledge and competence are gained through interaction and being actively involved in the learning process. The lecturer's role is purely that of a facilitator, allowing students to interact and increasing the effectiveness of the learning activity.

The Teaching and Learning Model (2012) of the Vaal University of Technology illustrates sound commitment to work-integrated learning or service learning. Engelbrecht (2003), as quoted in the Vaal University of Technology's Teaching and Learning Model (2012:66), defines work-integrated learning as specific knowledge and skills acquired though work and directly related to classroom teaching. It implies a concurrent process - it is a form of education that integrates periods of academic study with periods of learning through work experience in positions relating to the student's field of study.

Beaty (2000:137), as quoted in the Vaal University of Technology's Teaching and Learning Model (2012:68), describes two basic ways of making experiential learning an integral part of course design:

- Provide opportunities for experience in the form of structured and pre-planned practical work which will develop deeper understanding of concepts, skills and techniques within the controlled environment of the university.

- Give students the opportunity to learn from experience within the naturalistic environment in a work placement.

Laboratory experiments, simulations, case studies, micro teaching and projects are suggested by Beaty (2000:137-139) to enhance experiential learning inside the university, as quoted in the Vaal University of Technology's Teaching and Learning Model (2012:68). Beaty (2000), as quoted in the Vaal University of Technology's Teaching and Learning and Teaching Model (2012:69), proposes that experiential learning outside the university be achieved via field trips, placements and work-based learning projects. In the authors' view in the context of this article, integrated learning or service learning embraces the third element of quality assurance, 'Relevance'. The effectiveness of the teaching can be measured in the student's ability to deliver and succeed in the workplace.

\subsection{The problems which influence effectiveness at the Vaal University of Technology}

Problems could be analogous to barriers. In line with this thought, Horn et al. (2009:90) define barriers as obstacles that prevent movement or access. The following problems which influence effectiveness in the institution are encountered at Vaal University of Technology:

\subsection{Language problems}

In classrooms we daily face situations where a language gap exists between students and facilitators. English, as my second language, creates a noticeable gap between me as a facilitator and my students of African origin. Save the 
Children (2009) reported that in many countries in the world, large numbers of children start school only to find their teachers speaking to them in a language they do not understand. In other places, teachers start by communicating with children in their own language, but soon, as written words and numbers are introduced, teachers use a language children do not understand. In these situations, many children drop out of school altogether, while others fail their examinations and spend years repeating grades.

Kelly and McGowen (2010:61) argue that if you don't speak the language you will have trouble communicating, but even among people who share the same language, slang, jargon and regional accents can interfere with meaning. Nzimande (2012) announced during the SADTU National Council in Kempton Park that Foundation Phase teacher education programmes will be more able to respond specifically to the need to prepare teachers to teach in diverse language contexts, rather than focus only on the preparation of teachers for English or Afrikaans language contexts, as is presently the case in many institutions. We have made great strides towards establishing Foundation Phase teaching as an important focus of Teacher Education programmes offered at our institutions. These are exciting times for teacher education and development.

\subsection{Educational barrier problems}

The educational industry itself contributes to educational learning which influences the success and failure of learners. More implementation and commitment is needed by both the public sector and private sector. We acknowledge the path education has travelled and celebrate all achievements but the existing gaps need urgent attention to enhance educational learning.

According to Ryan (2010:184), there are two main kinds of barriers faced by learners:

- Contextual and systematic barriers, which occur as a result of the context or the system of education that learners find themselves in. Examples of these are negative attitudes towards or stereotyping of people who are 'different', an inappropriate word of instruction and non-involvement of parents. These barriers are not unique to learners as individuals, as all learners in the same context or system will experience the same contextual and systematic barriers.

- Intrinsic barriers, which are internal to the learner. These barriers can be overcome only if learners are helped as individuals. Changing the school system will not help the learner or eliminate these barriers. Examples of these are particular life experiences (for example, learners with a history with abuse might be less likely than their peers to succeed in a learning environment), socio-economic deprivation (like poverty or hunger), and physical, intellectual and developmental impairments. These are unique to learners as individuals.

Sharma and Mahapatra (2007:312) argue that education is at the crossroads of an integrated and an inclusive education system. Teachers and implementers are confused by the concepts. There are too many efforts implemented at school level in SA, but some of the barriers are still there, such as the lack of barrier-free schools, classes and other physical infrastructure. There is less space per child for performing academic activities in the classrooms.

\subsection{Social barrier problems}

Within the classroom it is possible to observe that our learners are harmed by society just as badly as by abusive experiences, poverty and lack of infrastructure. Society consists of our family, neighbours, friends, peers, church and the media. It is made up of the people who are supposed to protect us and keep us safe. When a social barrier exists for a learner it is evident in the learner's educational learning.

Sharma and Mahapatra (2007:311) argue that society attaches a stigma to children with special needs and that this varies according to the severity of the problem. Parents, siblings, peers, teachers all have the same attitude. They create barriers, knowingly or unknowingly, instead of removing them. Sometimes parents are over-protective of such children. They may be reluctant to show them off and avoid taking them to social gatherings.

\subsection{Economic problems: Poverty}

The Department of Education (2009:62) states that family structural characteristics play a vital role in understanding and determining teenage behaviours. Horn et al. (2009:121) defines poverty as the shortage of basic things that many people take for granted, such as food, clothing, shelter and safe drinking water, that afford a minimum standard of well-being and life. These are all material needs and represent the economic aspects of poverty. Horn, Huygen, Woodward and 
Smith (2009:108) argue that child-headed households are an increasing phenomenon in South Africa. For the children heading the household as well as the other children within the household education is not important, as they focus only on survival.

\subsection{Discipline in educational institutions}

Classrooms are challenged daily with poor standards of discipline and behaviour. As lecturers or facilitators we struggle to create an academic environment in the classrooms or lecture halls. Concern over the behaviour of students enjoys much attention on committee and structural meetings. Personal safety concerns demotivate staff in the performance of their much-loved occupation.

Matlala (2011) from Sowetan Online Newspaper, quoting John Maluleka, national secretary of South African Democratic Teachers Union (SADTU), wrote that an estimated 67000 teachers resigned that year because of lack of discipline in schools and lack of support from the Department of Education. Maluleke argued that corporal punishment was used as a strategy to instil discipline in schools and that since corporal punishment was outlawed, violence in schools was escalating. Maluleke maintains that teachers are afraid to discipline pupils because some carry pangas while others bring drugs onto the school premises and rape female pupils in the toilets. Gauteng topped the list of the number if teachers resigning as a result of lack of discipline at schools and also has the highest number of incidents of crime.

\subsection{Unplanned pregnancies}

A major challenge in classrooms is unplanned pregnancies. The responsibility of caring for a child carries major consequences for the young mother.

The Department of Education (2009:47) discussed the following educational consequences of early childbearing among teenagers in South Africa, with specific focus on school-going learners: school dropout, school absenteeism, poor academic performance, lower educational attainment, poorer cognitive development of children, and poor educational outcomes for children.

\subsection{Issues related to HIVI AIDS}

The educational community struggles with the epidemic of HIVIAIDS infections. A large number of our learners are orphaned by this global epidemic. It has several implications and puts pressure on the education and progress of learners. The Department of Higher Education and Training (2010) observes that the government is acting forcefully with regard to the epidemic and several initiatives and programmes are managed and driven from governmental seats. Successful initiatives include:

The Higher Education HIVIAIDS Programme (HEAIDS):

A dedicated national facility to develop and support the HIV mitigation programmes in South Africa's public Higher Education Institutions (HEIs). HEAIDS is an initiative of the Department of Higher Education and Training that is undertaken by Higher Education South Africa (HESA), the representative body of South Africa's 23 public Higher Education Institutions. HEAIDS supports higher education institutions in responding to the pandemic through their core functions of learning and teaching, research and innovation, and community engagement.

\subsection{Political problems: Teacher Union, SADTU affiliated to ANC and SACP}

Politics and political stability influence the effectiveness of the institution. Politics cannot be separated from education. The well-being of teachers is guarded by the South African Teachers' Union. SADTU strongly condemns crime and poor discipline in schools. When SADTU announces strikes and marches to publicise disputes, it negatively influences learning facilitation.

Matlala (2011) from Sowetan Online Newspaper quoted John Maluleka, national secretary of South African Democratic Teachers Union (SADTU), who pleaded with parents to assist teachers in their effort to discipline children.

According to Nzimande (2012), the Department has set a target of 12000 new teachers to be produced annually by the higher education system by 2014. The DHET is indeed committed to the establishment of a strong teacher education and development system; SADTU is also committed to this goal, and the creation of a professional 
development institute that will provide professional development opportunities for members deserves praise.

\subsection{Inadequately qualified lecturers}

Throughout the educational industry there is a lack of properly qualified staff. Experienced lecturers contribute to the success and effectiveness of learning.

\subsection{Physical, mental, sensory, neurological and developmental impairment}

Horn et al. (2009:91) explain that physical impairments refer to people who have difficulty in walking and/ or running. According to Horn et al. (2009:92), a person is considered mentally impaired when that person's cognitive functioning is below average and the person has deficits in two or more adaptive behaviours. People with sensory impairments include people who are deaf or blind (Horn et al. 2009:92).

Horn et al. (2009:91) define neurological impairment as damage to the nervous system, part of which is made up of the brain and spinal cord. The following conditions are classified as neurological disorders: epilepsy, cerebral palsy, brain tumours and dyslexia.

\subsection{Issues of quality in higher education}

Quality is defined by Ball (1985), Reynolds (1986) and Brennan et al. (1992) from a more pragmatic and epistemologically more viable approach, as 'fitness for purpose' as quoted by Craft (1994:170). On the other hand, the South African Qualifications Authority (SAQA) (2000:7) postulates that 'quality is not a thing, quality is an ongoing event'. Nightingale et al. (1994:7) allocated five approaches to quality: quality equals high standards, quality as consistency or zero defects, quality as fitness for purpose (shared with Ball et al.), quality as value for money and quality as transformative. In the context of this article, quality is a process of ensuring the maintenance of value for money. Quality in the context of education is pricey when it is self-financed. Therefore the onus lies on the role-players to ensure value and meet the expectations of the students.

Student tuition and learner support contribute to the quality of higher education. Quality assurance enjoys global attention. Sallies (2013:1) contends that quality is an idea whose time has come. It is on everyone's lips. The new consciousness of quality has now reached education; educational institutions are being required to develop their own approaches to quality and need to demonstrate publicly that they can deliver a service of consistent quality. No longer are quality, quality assurance, total quality and TQM new initiatives or another set of fads designed to add to the workload of already over-worked teachers and under-funded institutions; while initiative fatigue has been a symptom of a hard-pressed education system, quality improvement should not be. The best organisations, whether public or private, understand quality and know its secret. Seeking the source of quality is an important aspect. Sallies (2013:2) posits that the sources of quality are:

- Outstanding teachers;

- High moral values;

- Excellent examination results;

- The support of parents, business and the local community;

- Plentiful resources;

- The application of the latest technology;

- Strong and purposeful leadership;

- The care and concern for pupils and students; and

- A well-balanced and challenging curriculum.

Learner support in the form of the availability of textbooks and other apparatus used in the teaching method practised influences the quality of education and the quality assurance process in general. According to the South Wales Department of Education and Training (2003:5), the features of classroom practice that have been linked to improved student outcomes can be characterised as representing three dimensions of pedagogy:

- Pedagogy that is fundamentally based on promoting high levels of intellectual quality;

- Pedagogy that is soundly based on promoting the quality of the learning environment; and

- Pedagogy that develops and makes explicit to students the significance of their work.

Morgan (2013), a journalist from The Times of India online newspaper, maintains that, in a growing country of 1.2 
billion people, home to a third of the world's poorest, education - or the lack of it - can make an enormous difference to people's lives. The Times of India, the nation's most popular English-language newspaper, is dominated by higher education issues. In my view, education should be aligned to a quality assurance process to ensure its quality, standards and relevance, or else it will be a squandered attempt. Martin, Jucker and Martin (2009:2) investigated current developments in quality assurance and enhancement in the UK's education sector and how this evolving agenda is approaching the question of integrating sustainable development within it.

According to Martin et al. (2009:8), the factors which are recognised to contribute to effective learning are:

- A whole-school commitment;

- A well-developed local support network, including local education authorities and/ or NGOs;

- Effective use of the economy as a learning source by fostering links with individuals and groups in the neighbourhood;

- Giving people both individual and collective responsibility in looking after and improving their learning environments;

- A well-planned curriculum;

- Clear objectives on the part of the teachers; and

- Active involvement of pupils in initiatives that promote sustainability.

Martin et al. (2009:10) posit that the following seven categories of quality framework should be instilled in students:

- In-depth knowledge of a favourite subject;

- How to apply knowledge;

- What makes a good life;

- How others think;

- How change happens;

- The dynamics of power and influence; and

- Global interdependence.

\subsection{Assuring Standards in higher education}

Standards, as defined by the South African Qualifications Authority (SAQA) (2000:5), are expressed in terms of a nationally agreed framework and internationally acceptable outcomes. Barnet (1992a) postulates that standards are a set of criteria against which an enterprise is judged (Nightingale et al. (1994:8). In my view and in the context of this assignment, standards are about enabling an alignment between what is offered and the policies and agenda of government - delegated from a national level to the level where it reaches the higher education institution.

Australian Higher Education (2013:1) argues that, despite regular commentary on standards in higher education, there is little consensus about what they are. Standards become even more opaque when we talk specifically about academic standards because many of the activities concerning standards in the academic arena are based on implicit, tacit practices, as quoted from James (2003). Academic standards are largely unknown and intangible especially to those outside of teaching and learning practice.

Australian Higher Education (2013:1) postulates that standards are viewed in two ways:

- A set of general principles or practice (which requires qualitative interpretation); and

- A set of explicit thresholds - these thresholds tend to describe expectations and are set as minimum and normative standards.

The authors are of the opinion that the student tuition and learner support relevant to standards exist in a challenged paradigm. Australian Higher Education (2013:2) observes that one person or a group sets standards and these standards are then achieved by another person or another group. Four distinct activities are identified by Australian Higher Education (2013:2):

- Setting of standards;

- Monitoring of standards;

- Achievement of standards; and

- Assessment of standards.

Setting of standards is complex, but a necessity in higher education. Standards should be demonstrable and measureable. They are set against national levels, and in South Africa the National Qualifications Framework provides the guidelines for this exercise. The people involved in setting standards constantly change and with changed decision 
makers come changed expectations.

\subsection{The purpose of Relevance in higher education}

Relevance is defined by the South African Qualifications Authority (SAQA) (2000:7) as being and remaining responsive to national developments; Dlamini (2009:17) agrees and provides the same definition. In my view and in the context of this assignment, relevance is about providing a curriculum which is in line with the prospects of the industry: training and teaching students in such a way that the learning material relates to the current workplace situation, keeping pace with changes and trends.

Relevance, in the context of student tuition, requires that the assessment of students should prepare them for the workplace and national development, according to the definition by South African Qualifications Authority (SAQA) (2000:7). The University of Arkansas (2011:2) suggests that Blooms Taxonomy helps to identify where the students are and where their professor expects them to be on the pyramid for a particular class or subject. Knowing the position on the pyramid assists in developing learning strategies that are most appropriate, effective, and efficient.

In relation to learner support, the following are key themes for inspection methodology which relate to relevance in higher education Martin et al. (2009:5):

- Management - focusing on the school mission statement; policy statement; senior involvement and support; references in the school development plan; allocation of resources; role of the governing body; guidance on implementation in the curriculum; relevant professional development; and auditing, monitoring and sustainability of projects.

- Curriculum - focusing on planning; inclusion and identification within current schemes of work and lesson planning; and evidence of cross-curricular mapping.

- Teaching - focusing on positive role models; use of local case studies; engaging in local issues; links with and use of associations; use of topicality; active learning; exploring issues leading to action on behalf of pupils; evidence in displays of work; global links; and field visits.

- Learning - focusing on independent styles of learning; children developing their own reasoned points of view; pupils as active citizens within the classroom, school and community; active participation in reducing waste; and active decision-making.

- Decision-making - focusing on active involvement in a school or eco-council; example of whole-school participation and co-operation; playground committee; active environmental group; networking and community involvement; feedback mechanisms for students to talk about school issues; and pupil-parent-teacher working groups.

- Specific projects - focusing on details of specific initiatives that the school may be involved in; links with NGOs or other areas of support; and details of each project context.

- General environmental indicators, purchasing and grounds and learning environment - focusing on an ecocode; waste minimising; recycled products; environmentally friendly purchasing; and recycling schemes.

The emphasis is always on the good capabilities of the lecturer and not enough on the relevance of what the good lecturer presents in lecture halls, which relates to the actual workplace- and to the developments, changes and trends in the workplace. Higher education should expose students to the relevant work-place and specific field of study whether through simulation or field trips, as proposed by the Vaal University of Technology Learning and Teaching Model (2012:69).

\section{Conclusion}

In the view of The South Wales Department of Education and Training (2003:5), the three dimensions of pedagogy focus on a quality learning environment, intellectual quality and significance. Quality is therefore both an internal and an external element.

Quality cannot be separated from education; the element, as part of quality assurance, complements 'value' and 'worth' in education. Nelson Mandela said, 'Education is the most powerful weapon which you can use to change the world.' This approach is clearly followed in poor and heavily populated countries like India which, according to The Times of India (2013) in a newspaper article titled 'India's higher education sector focuses on standards', has set targets to create capacity for an extra 10 million students over the next five years on top of the existing 25.9 million in the system in 2011/12. 
In agreement with Australian Higher Education (2013:1), standards in higher education are under-discussed and under-researched, owing to the intangible nature of this element. The setting of standards is a constantly changing process and with changed decision makers come changed expectations. As a result, South African Higher Education can clearly differentiate between the different 'eras' characterised by different minsters of education: the Bengu era, the Asmal era and the Nzimande era. Changes which are seen as transformation are very noticeable in South African educational institutions.

The setting of standards should be the responsibility of institutions and individual academic staff at the institutions but the pressure to adhere to national and international standards conflicts with this approach to the setting of standards, which are defined by the South African Qualifications Authority (SAQA) (2000:5) as being expressed in terms of a nationally agreed framework and internationally acceptable outcomes.

Relevance as a quality assurance element requires students to take charge of their own learning by engaging with stakeholders in their field of study. The responsibility for class time and arranged exposure to the field should not be restricted to the lecturer and the institution.

This paper looked at the three elements of quality assurance, namely quality, standards and relevance. From the literature it is evident that quality is related to value for money and fitness for purpose. However, in practice, education often neither gives value for money nor serves its purpose. A typed and ring-bound test or typed assignment or wellplanned examination is considered as quality. With regard to standards, the literature revealed that such standards must refer to the national framework. However, the individuals or committees determining these standards are not well informed or trained in the field for which they are setting standards. Ironically, knowledgeable individuals or committees must adhere to standards which are sometimes not even pre-tested. When interrogating relevance, the literature emphasises national developments, yet these developments are not included in the curriculum since course materials for several courses date back more than 10 years. The literature is outdated and not relevant to the current situation.

In conclusion, the elements of the quality assurance process in higher education and the desired goal of this process are a matter for concern for Universities of Technology in South Africa.

\section{References}

Australian Higher Education (2012) Setting standards in Australian Higher Education. [Online]. Available at: <http://www.aair.org.au larticles/volume-17-no1/17-1-setting-standards-in-australian-higher-education>. Accessed: 22/8/2013.

Badat S (2010) The challenges of transformation in higher education and training institutions in South Africa. Development Bank of South Africa. Midrand, Pretoria.

Craft A (1994) International developments in assuring quality in higher education. London, UK: The Falmer Press.

Department of Education (2009) The Department of Education home page. [Online]. Available at: http://www.education.gov.za.za/LinkClick.aspx?fileticket=ulqj\%2BsyyccM\%3D\&

Accessed: 15/8/2013.

Dlamini U (2009) Conduct Outcomes-based Assessment. Johannesburg: Bathon House Multi Media CC.

Higher Education HIVIAIDS Programme (2010) HIVIAIDS in Higher Education. [Online]. Available at: <http://www.heaids.org.za>. Accessed: 15/8/2013.

Horn N Huygen P, Woodward S and Smith K (2009) Human and Social Development National Qualification Framework Level 3: Student's Book. Northlands: Mcmillan.

Kelly M and M C Gowen J (2010) BUSN3: Student Edition. Mason, OH: South-Western Cengage Learning.

Kruger S (2010) Art and Science of Teaching: National Qualifications Framework Level 4. Cape Town: Juta \& Company Ltd.

Martin S, Jucker R and Martin M (2009) Quality and education for sustainable development current context and future opportunities. London, UK: NOVA Science Publishers, Inc.

Matlala A (2011) Teachers quit over lack of discipline. [Online]. Available at: <http://www.sowetanlive.co.za/news/2011/12/21/teachersquit-over-lack-of-discipline>. Accessed: 15/8/2013.

Morgan J (2013) India's higher education sector focuses on standards. [Online]. Available at: <http://www.timeshighereducation.co.uk Ifeatures/inias-higher-education-sector-focuses-on-standards/2005767.article>. Accessed: 28/8/2013.

New South Wales Department of Education and Training (2003) Quality teaching in NSW public schools. [Online]. Available at: $<$ http://www.det.nsw.edu.au/proflearn/docs/pdf/qt_EPSColor.pdf >. Accessed: 22/8/2013.

Nightingale P, O'Neil M (1994) Achieving quality learning in higher education. London, UK: Kogan Page Limited.

Powell K C and Kalina C J (2009) Cognitive and Social constructivism: Developing tools for an effective classroom. Academic Journal article for Education. 2 (130): 241-243.

Council on Higher Education (2013) A proposal for undergraduate curriculum reform in South Africa: The case for a flexible curriculum structure. Discussion Document. Pretoria: CHE.

Ryan M (2010) Human and Social Development National Qualification Framework Level 4: Student's Book. Northlands: Mcmillan.

Sallis E (2013) Total quality management in Education. London, UK: Routledge. 
Save the Children (2009) Steps Towards Learning: A guide to overcoming language barriers in children's education. [Online]. Available

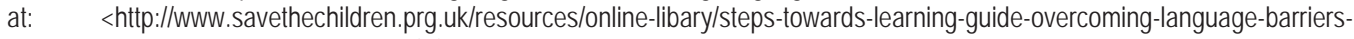
children\%E2\%80\%99s>. Accessed: 15/6/2013.

Sharma K and Mahapatra B C (2007) Emerging Trends in Inclusive Education. New Delhi: IVY Publication House.

South African Qualifications Authority (2000) The National Qualifications Framework and Quality Assurance. [Online]. Available at: http://www.saqa.org.za/structure/nqf/docs/quality_assure.pdf>. Accessed: 20/8/2013.

University of Arkansas (2011) Blooms Taxonomy. [Online]. Available at: <elc.uark.edu/wp-content/uploads/2011/07/Using-BloomsTaxonomy-for-Successful-Learning.pdf >. Accessed: 28/8/2013.

Vaal University of Technology (2012) Teaching and Learning Model: Vanderbijlpark.

Van der Horst H and Mcdonald R (1997) Outcomes-based education. A teachers' manual. Pretoria: Kagiso publishers. 
